\title{
Insulin Receptor
}

National Cancer Institute

\section{Source}

National Cancer Institute. Insulin Receptor. NCI Thesaurus. Code C17072.

Insulin receptor (1382 aa, 156 kDa) is encoded by the human INSR gene. This protein plays a role in both signal transduction and glucose homeostasis. 